\title{
METODE JALUR KRITIS DAN PENDEKATAN PROGRAM LINIER PADA MASALAH MANAJEMEN PROYEK
}

\author{
RISNA JULITA, MAHDHIVAN SYAFWAN, BUDI RUDIANTO \\ Program Studi Matematika, \\ Fakultas Matematika dan Ilmu Pengetahuan Alam, Universitas Andalas, \\ Kampus UNAND Limau Manis Padang, Indonesia, \\ Risnajulita27@gmail.com
}

\begin{abstract}
Abstrak. Salah satu permasalahan dalam proyek adalah menyelesaikan masalah manajemen proyek secara optimal. Masalah manajemen proyek tersebut dapat diselesaikan dengan menggunakan metode jalur kritis dan pendekatan program linier. Pada metode jalur kritis, penyelesaian masalah manajemen proyek untuk menentukan jalur kritis diidentifikasi dengan mencari variabel slack. Dan pada pendekatan program linier, jalur kritis bisa dicari menggunakan solver program linier pada Microsoft Excel 2010. Dari jalur kritis ini dapat ditentukan durasi penyelesaian proyek pada kondisi normal (tidak ada penundaan pada setiap kegiatan proyek). Kedua metode tersebut juga dapat digunakan untuk mempercepat penyelesaian proyek yang disebut crashing. Crashing pada metode jalur kritis dicari dengan melakukan analisis marjinal pada data time-cost tradeoff dan pada pendekatan program linier dicari dengan menggunakan solver program linier Microsoft Excel 2010. Kedua metode dalam menyelesaikan masalah program linier tersebut menghasilkan nilai optimum yang sama.
\end{abstract}

Kata Kunci: Program Linier, Metode Jalur Kritis, Slack, time-cost trade-off, Crashing

\section{Pendahuluan}

Dalam dunia kerja saat ini sangat dibutuhkan sekali koordinasi di berbagai bidang organisasi untuk menyelesaikan suatu proyek dengan baik. Proyek adalah rangkaian tugas atau kegiatan yang berhubungan dengan pencapaian beberapa tujuan yang direncanakan, biasanya tujuannya adalah tunggal dan tidak berulang [5].

Sebelum mengerjakan proyek, terdapat beberapa tahap pengelolaan proyek, yaitu tahap perencanaan, tahap penjadwalan dan tahap pengkoordinasian. Tahap yang paling menentukan untuk berhasil atau tidaknya suatu proyek yaitu tahap perencanaan dan tahap penjadwalan [2]. Tahap perencanaan merupakan dasar untuk proyek bisa berjalan dengan baik. Jika sebuah proyek tidak direncanakan dengan baik, maka waktu penyelesaian suatu proyek tidak dapat diperkirakan dengan tepat karena penyelesaian sebuah proyek itu bervariasi. Adapun penjadwalan adalah tahap ketergantungan dari berbagai aktivitas yang membangun proyek secara keseluruhan dan disusun secara sistematis dengan sumber daya yang digunakan secara efektif dan efisien.

Untuk menyelesaikan masalah manajemen proyek digunakan dua metode penjadwalan yaitu metode jalur kritis [critical path method (CPM)] dan pendekatan 
program linier (linier programming) [2]. Metode jalur kritis pada dasarnya merupakan metode penjadwalan yang berorientasi pada waktu. Tujuan dari metode jalur kritis adalah untuk membangun hubungan antara waktu dan biaya proyek dengan mengurangi target waktu dan mempertimbangkan biaya operasional [4].

Program linier sendiri merupakan metode matematika yang banyak digunakan dalam menyelesaikan masalah optimasi linier di berbagai bidang. Permasalahan yang akan dikaji adalah bagaimana penggunaan metode jalur kritis dan pendekatan program linier pada masalah manajemen suatu proyek sehingga dapat ditentukan lamanya waktu penyelesaian proyek tersebut dengan biaya penyelesaian yang minimal dengan mengeksplorasi kembali pembahasan pada referensi [3] dan menerapkannya pada kasus proyek yang ada pada referensi [4].

\section{Manajemen Proyek dengan Metode Jalur Kritis}

Suatu jaringan yang digunakan untuk merepresentasikan pengerjaan proyek dinamakan jaringan proyek (project network). Suatu jaringan proyek terdiri dari simpul (ditampilkan sebagai lingkaran kecil atau persegi panjang) dan busur (ditampilkan sebagai panah) untuk menghubungkan simpul-simpul yang berbeda. Suatu path pada jaringan proyek adalah rute yang melalui busur-busur dari simpul "mulai" sampai simpul "selesai". Panjang dari jalur adalah total dari (perkiraan) durasi kegiatan-kegiatan pada jalur tersebut [3]. Jelas bahwa (perkiraan) durasi keseluruhan proyek sama dengan panjang dari jalur terpanjang yang melalui jaringan proyek. Jalur terpanjang tersebut dinamakan jalur kritis (critical path) [3].

Pada penjadwalan setiap unit kegiatan perlu ditentukan kapan waktu mulai dan waktu selesai jika tidak terjadi penundaan. Waktu mulai dan waktu selesai dari setiap kegiatan jika tidak terjadi penundaan dalam proyek disebut Earliest Start Time (ES) dan Earliest Finish Time (EF) dari kegiatan tersebut [3].

Hubungan antara ES dan EF dapat dirumuskan sebagai berikut:

$$
\mathrm{EF}=\mathrm{ES}+(\text { perkiraan}) \text { durasi kegiatan }
$$

Untuk menentukan ES, digunakan aturan berikut [3]:

(i) Jika suatu kegiatan hanya mempunyai satu kegiatan pendahulu, maka

$\mathrm{ES}$ untuk kegiatan tersebut $=\mathrm{EF}$ dari kegiatan pendahulu.

(ii) Jika suatu kegiatan mempunyai lebih dari satu kegiatan pendahulu, maka

ES untuk kegiatan tersebut $=\mathrm{EF}$ maksimum dari kegiatan-kegiatan pendahulunya.

Selanjutnya juga dikenal Latest Start Time (LS), yaitu waktu paling akhir setiap kegiatan dapat dimulai tanpa adanya penundaaan pada penyelesaian proyek (sehingga simpul "selesai" masih dicapai pada waktu selesai yang paling awal). Kemudian Latest Start Time (LF) memiliki definisi yang bersesuaian dengan penyelesaian kegiatan tersebut.

Hubungan antara LS dan LF adalah 


$$
\mathrm{LS}=\mathrm{LF}-(\text { perkiraan}) \text { durasi kegiatan. }
$$

Untuk menentukan LF digunakan aturan berikut [3]:

(i) Jika suatu kegiatan mempunyai satu kegiatan lanjutan, maka

LF untuk kegiatan tersebut $=$ LS dari kegiatan lanjutannya.

(ii) Jika suatu kegiatan mempunyai lebih dari satu kegiatan lanjutan, maka

LF untuk kegiatan tersebut $=$ LS minimum dari kegiatan-kegiatan lanjutannya.

Slack untuk suatu kegiatan adalah selisih antara waktu selesai paling akhir dan waktu selesai paling awal dari kegiatan tersebut, atau dapat dirumuskan sebagai berikut:

$$
\text { slack }=\mathrm{LF}-\mathrm{EF} .
$$

Karena LF - EF = LS - ES, maka slack juga dapat dihitung dengan

$$
\text { slack }=\text { LS - ES. }
$$

Setiap kegiatan yang mempunyai nilai slack nol $(\mathrm{LF}-\mathrm{EF}=0)$, maka kegiatan tersebut berada pada jalur kritis, artinya setiap penundaan yang terjadi di sepanjang jalur ini akan menyebabkan penundaan pada penyelesaian proyek secara keseluruhan [3].

Crashing suatu kegiatan mengacu pada langkah-langkah khusus (yang mengeluarkan biaya) untuk mengurangi durasi penyelesaian dari kegiatan tersebut. Crashing proyek mengacu pada crashing sejumlah kegiatan untuk mengurangi durasi penyelesaian proyek di bawah waktu normal.

Metode CPM untuk time-cost trade-off adalah metode CPM yang berkaitan dengan menentukan berapa banyak (jika ada) crash untuk masing-masing kegiatan yang dapat dilakukan dalam rangka mengurangi durasi proyek ke waktu yang diinginkan [3].

\section{Penerapan Metode Jalur Kritis dan Pendekatan Program Linier Pada Masalah Manajemen Proyek}

Untuk penerapan digunakan suatu proyek konstruksi yang bernama Reliable Co. Perusahaan konstruksi Reliable Co tersebut baru saja memenangkan tender $\$ 6,500,000$ untuk pembangunan apartemen baru. Pembangunan apartemen tersebut mesti diselesaikan kurang dari dua tahun. Untuk itu, dibuatlah kontrak sebagai berikut:

- Jika pembangunan apartemen tersebut tidak selesai dalam 80 minggu, maka Reliable Co akan dikenakan denda sebesar $\$ 1,980,000$.

- Jika pembangunan apartemen tersebut selesai lebih cepat yaitu dalam waktu 50 minggu, maka Reliable Co akan diberikan bonus sebesar $\$ 990,000$.

Pada Tabel 1 diberikan daftar kegiatan dari proyek konstruksi Reliable Co tersebut. Dalam hal ini, data pada kolom ke-3 dan ke-4 diambil dari referensi [3]. 
164 Risna Julita dkk.

Tabel 1. Daftar Kegiatan Proyek Konstruksi Reliable Co

\begin{tabular}{|c|c|c|}
\hline Kegiatan & Kegiatan Pendahulu & Perkiraan (Durasi) \\
\hline$A$ & & 2 Minggu \\
\hline$B$ & A & 3 Minggu \\
\hline${ }_{D}^{C}$ & ${ }_{C}^{B}$ & $\begin{array}{l}2 \text { Minggu } \\
2 \text { Minggu }\end{array}$ \\
\hline E & ${ }_{D}$ & 4 Minggu \\
\hline$F$ & $B$ & 3 Minggu \\
\hline$G$ & ${ }_{E}^{E, F}$ & 2 Minggu \\
\hline${ }_{I}^{H}$ & ${ }_{H}^{G}$ & $\begin{array}{l}10 \text { Minggu } \\
15 \text { Minggu }\end{array}$ \\
\hline$J$ & ${ }_{H}^{H}$ & 7 Minggu \\
\hline $\begin{array}{l}K \\
L\end{array}$ & ${ }_{J K}^{I}$ & $\begin{array}{l}2 \text { Minggu } \\
9 \text { Minggu }\end{array}$ \\
\hline$M$ & $\stackrel{\mathrm{H}}{\mathrm{J}}$ & 2 Minggu \\
\hline$N$ & $H_{H}$ & 3 Minggu \\
\hline$O$ & $H$ & 6 Minggu \\
\hline Q & $\frac{1}{L, M}$ & $\begin{array}{l}7 \text { Minggu } \\
\text { 4 Minggu }\end{array}$ \\
\hline${ }_{R}^{R}$ & $O, Q$ & 6 Minggu \\
\hline$S$ & $N, R$ & 7 Minggu \\
\hline $\begin{array}{l}T \\
U\end{array}$ & $\begin{array}{l}J, P \\
S\end{array}$ & $\begin{array}{l}5 \text { Minggu } \\
5 \text { Minggu }\end{array}$ \\
\hline$V$ & ${ }_{T}^{T}$ & 4 Minggu \\
\hline Total & & $\frac{\frac{4 \text { Minggu }}{114 \text { Minggu }}}{\frac{1}{10}}$ \\
\hline
\end{tabular}

Pada jaringan proyek berskala kecil seperti Gambar 1, penentuan jalur kritis dengan mendata seluruh jalur yang mungkin dan kemudian mencari jalur yang terpanjang masih mudah untuk dilakukan. Namun, untuk jaringan proyek berskala besar, cara seperti ini tentunya menjadi tidak efisien. Sebagai alternatif, digunakan metode jalur kritis yang memberikan prosedur yang sistematis sehingga perhitungannya dapat dibuat lebih efisien (melalui program). Berikut dijelaskan langkahlangkahnya dengan perhitungan manual yang diterapkan pada proyek konstruksi Reliable Co.

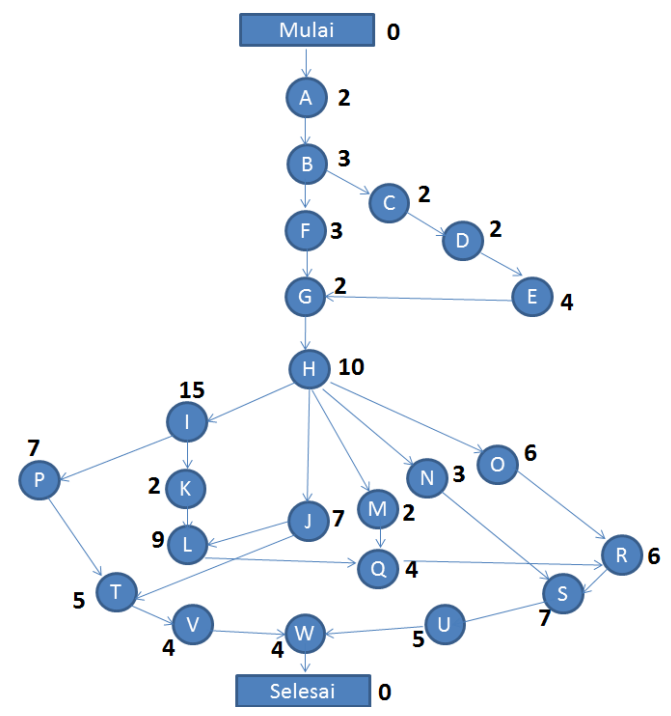

Gambar 1. Jaringan Proyek Konstruksi Reliable Co

A. Penjadwalan setiap unit kegiatan 


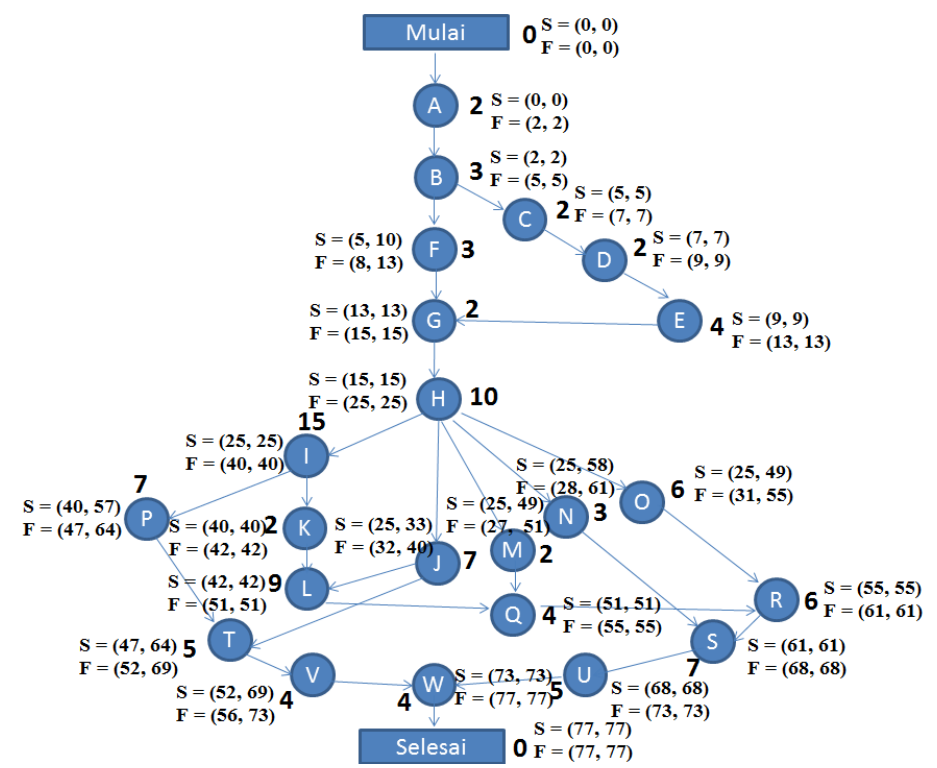

Gambar 2. Keseluruhan nilai ES dan LS serta EF dan LF dari Proyek Konstruksi Reliable Co

(1) Menentukan nilai ES (earliest start time) dan EF (earliest finish time),

(2) Menentukan nilai LS (latest start time) dan LF (latest finish time).

B. Identifikasi slack pada penjadwalan

Untuk mengidentifikasi slack pada jaringan proyek, digunakan gabungan antara $\mathrm{S}=(\mathrm{ES}, \mathrm{LS})$ dan $\mathrm{F}=(\mathrm{EF}, \mathrm{LF})$ yang digambarkan dalam diagram jaringan proyek pada Gambar 2.

Untuk mencari kegiatan yang berada pada jalur kritis dan yang tidak berada pada jalur kritis, maka dicari nilai slack yang bisa dilihat pada Tabel 2 (suatu kegiatan berada pada jalur kritis jika nilai slack-nya nol, dan sebaliknya).

Dari tabel tersebut diperoleh jalur kritis sebagai berikut:

Mulai $\rightarrow A \rightarrow B \rightarrow C \rightarrow D \rightarrow E \rightarrow G \rightarrow H \rightarrow I \rightarrow K \rightarrow L \rightarrow Q \rightarrow R \rightarrow$ $S \rightarrow U \rightarrow W \rightarrow$ Selesai, dengan panjang 77 minggu (dengan total biaya sebesar $\$ 5,120,000)$. 
Tabel 2. Slack pada Proyek Konstruksi Reliable Co

\begin{tabular}{|c|l|c|}
\hline Kegiatan & Slack $($ LF-EF $)$ & Berada pada Jalur Kritis ? \\
\hline$A$ & $2-2=0$ & ya \\
$B$ & $5-5=0$ & ya \\
$C$ & $7-7=0$ & ya \\
$D$ & $9-9=0$ & ya \\
$E$ & $13-13=0$ & ya \\
$F$ & $13-8=5$ & tidak \\
$G$ & $15-15=0$ & ya \\
$H$ & $25-25=0$ & ya \\
$I$ & $40-40=0$ & ya \\
$J$ & $40-32=8$ & tidak \\
$K$ & $42-42=0$ & ya \\
$L$ & $51-51=0$ & ya \\
$M$ & $51-27=24$ & tidak \\
$N$ & $61-28=33$ & tidak \\
$O$ & $55-31=24$ & tidak \\
$P$ & $64-47=17$ & tidak \\
$Q$ & $55-55=0$ & ya \\
$R$ & $61-61=0$ & ya \\
$S$ & $68-68=0$ & ya \\
$T$ & $69-52=17$ & tidak \\
$U$ & $73-73=0$ & ya \\
$V$ & $73-56=17$ & tidak \\
$W$ & $77-77=0$ & ya \\
\hline
\end{tabular}

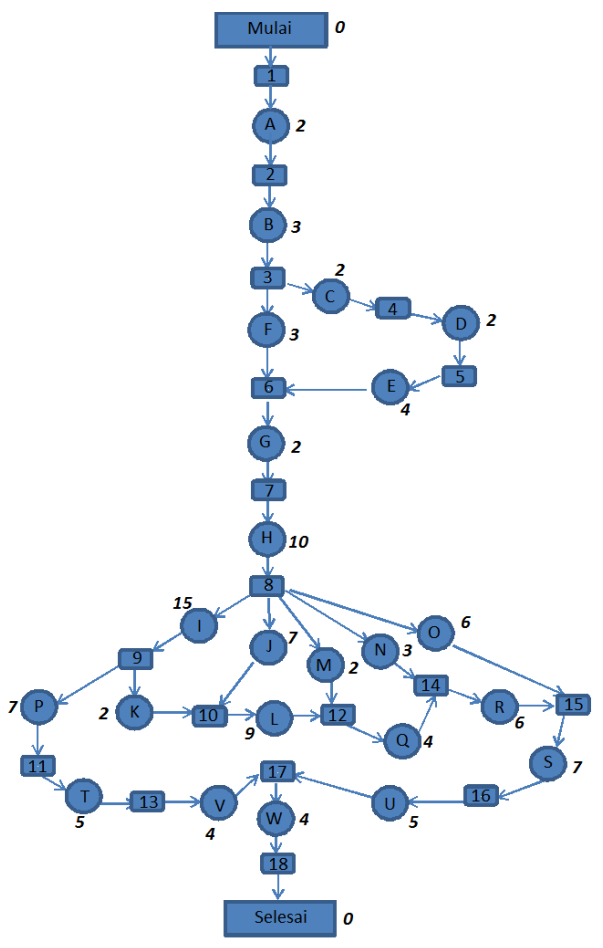

Gambar 3. Jaringan Proyek Konstruksi Reliable Co

Untuk menentukan jalur kritis dengan menggunakan pendekatan program linier, bentuk terlebih dahulu simpul 'imajiner' di setiap busur pada jaringan proyek. Misalkan simpul tersebut dikodekan dengan angka (lihat Gambar 3 pada jaringan proyek konstruksi Reliable Co).

Teknik program linier untuk menentukan jalur kritis adalah dengan melihat kegiatan yang masuk ke simpul imajiner dan keluar dari simpul imajiner. Misalkan 
pada suatu jaringan proyek terdapat $m$ simpul imajiner, dimana simpul 1 dan $m$ berturut-turut menyatakan simpul imajiner awal (setelah kegiatan 'mulai') dan simpul imajiner akhir (sebelum kegiatan 'akhir').

Fungsi tujuan dari program linier untuk masalah ini adalah:

$$
\max Z=\sum_{i=1}^{n} T_{i} Y_{i}
$$

dimana:

- $Z$ = durasi penyelesaian proyek pada jalur kritis,

- $T_{i}=$ waktu normal untuk kegiatan $i$,

- $Y_{i}=$ variabel keputusan untuk kegiatan $i$ apakah berada pada jalur kritis atau tidak $(1=$ "ya" dan $0=$ "tidak"),

- $n=$ banyak kegiatan.

Kendalanya diklasifikasikan dalam tiga kategori :

- untuk kegiatan yang memasuki simpul $m$ :

$$
\sum_{i=1}^{p} Y_{i}=1, \quad p<n
$$

- untuk kegiatan yang keluar dari simpul 1:

$$
\sum_{i=1}^{q} Y_{i}=1, \quad q<n
$$

- untuk kegiatan yang masuk ke dan keluar dari simpul $2,3, \ldots, m-1$ :

$$
+\sum_{i=1}^{r} Y_{i}-\sum_{i=1}^{s} Y_{i}=0, \quad r, s<n
$$

dimana tanda '+' dan '-' berturut-turut digunakan untuk kegiatan-kegiatan yang masuk ke dan keluar dari simpul $2,3, \ldots, m-1$. Dengan menggunakan contoh kasus pada masalah proyek konstruksi Reliable Co, diformulasikan model program linier sebagai berikut:

Fungsi tujuan:

maks $Z=2 Y_{A}+3 Y_{B}+2 Y_{C}+2 Y_{D}+4 Y_{E}+3 Y_{F}+2 Y_{G}+10 Y_{H}+15 Y_{I}+7 Y_{J}$ $+2 Y_{K}+9 Y_{L}+2 Y_{M}+3 Y_{N}+6 Y_{O}+7 Y_{P}+4 Y_{Q}+6 Y_{R}+7 Y_{S}+5 Y_{U}+5 Y_{T}+$ $4 Y_{V}+4 Y_{W}$.

Perhatikan bahwa pada kasus ini, terdapat 18 simpul imajiner (lihat lagi Gambar 3). Jadi fungsi-fungsi kendalanya adalah:

(1) Untuk kegiatan yang keluar dari simpul 1:

$$
\text { simpul 1: } Y_{A}=1 \text {. }
$$

(2) Untuk kegiatan yang masuk ke dan keluar dari simpul $2,3, \ldots, 17$ :

simpul 2: $Y_{A}-Y_{B}=0$,

simpul 3: $Y_{B}-Y_{C}-Y_{F}=0$,

simpul 4: $Y_{C}-Y_{D}=0$,

simpul 5: $Y_{D}-Y_{E}=0$,

simpul 6: $Y_{F}+Y_{E}-Y_{G}=0$,

simpul 7: $Y_{G}-Y_{H}=0$,

simpul 8: $Y_{H}-Y_{I}-Y_{J}-Y_{M}$ simpul 9: $Y_{I}-Y_{P}-Y_{K}=0$, simpul 10: $Y_{J}+Y_{K}-Y_{L}=0$, simpul 11: $Y_{P}-Y_{T}=0$, simpul 12: $Y_{M}+Y_{L}-Y_{Q}=0$, simpul 13: $Y_{T}-Y_{V}=0$, simpul 14: $Y_{N}+Y_{Q}-Y_{R}=0$, simpul 15: $Y_{O}+Y_{R}-Y_{S}=0$, 0, simpul 16: $Y_{S}-Y_{U}=0$, simpul 17: $Y_{V}+Y_{U}-Y_{W}=0$. 
Tabel 3. Hasil Perhitungan Jalur Kritis pada Proyek Konstruksi Reliable Co dengan menggunakan Solver Program Linier pada Microsoft Excel 2010

\begin{tabular}{|c|c|c|c|c|c|}
\hline Kegiatan & $\begin{array}{l}\text { Kegiatan } \\
\text { Pendahulu }\end{array}$ & $\begin{array}{c}\text { Waktu } \\
\text { Normal (Ti) }\end{array}$ & Nilai $Y i$ & Nilai $Z$ & $\begin{array}{l}\text { Berada pada } \\
\text { Jalur Kritis? }\end{array}$ \\
\hline$A$ & & 2 & 1 & 2 & $\mathrm{Ya}$ \\
\hline$B$ & $A$ & 3 & 1 & 3 & $\mathrm{Ya}$ \\
\hline C & $B$ & 2 & 1 & 2 & $\mathrm{Ya}$ \\
\hline$D$ & c & 2 & 1 & 2 & $\mathrm{Ya}$ \\
\hline$E$ & $D$ & 4 & 1 & 4 & $\mathrm{Ya}$ \\
\hline$F$ & $B$ & 3 & 0 & 0 & Tidak \\
\hline$G$ & $E, F$ & 2 & 1 & 2 & $\mathrm{Ya}$ \\
\hline $\mathrm{H}$ & $G$ & 10 & 1 & 10 & $\mathrm{Ya}$ \\
\hline 1 & $H$ & 15 & 1 & 15 & $\mathrm{Ya}$ \\
\hline $\mathrm{J}$ & $H$ & 7 & 0 & 0 & Tidak \\
\hline$K$ & 1 & 2 & 1 & 2 & $\mathrm{Ya}$ \\
\hline$L$ & $J, K$ & 9 & 1 & 9 & $\mathrm{Ya}$ \\
\hline$M$ & $\mathrm{H}$ & 2 & 0 & 0 & Tidak \\
\hline$N$ & $\mathrm{H}$ & 3 & 0 & 0 & Tidak \\
\hline 0 & $\mathrm{H}$ & 6 & 0 & 0 & Tidak \\
\hline$p$ & 1 & 7 & 0 & 0 & Tidak \\
\hline a & $L, M$ & 4 & 1 & 4 & $\mathrm{Ya}$ \\
\hline$R$ & 0,0 & 6 & 1 & 6 & $\mathrm{Ya}$ \\
\hline$s$ & $N, R$ & 7 & 1 & 7 & $\mathrm{Ya}$ \\
\hline$T$ & $J, P$ & 5 & 0 & 0 & Tidak \\
\hline$u$ & $s$ & 5 & 1 & 5 & $\mathrm{Ya}$ \\
\hline$v$ & $T$ & 4 & 0 & 0 & Tidak \\
\hline \multirow[t]{2}{*}{$w$} & $u, V$ & 4 & 1 & 4 & $\mathrm{Ya}$ \\
\hline & Waktu Penyelesaian proyek & 114 & & 77 & \\
\hline
\end{tabular}

(3) Untuk kegiatan yang memasuki simpul 18:

$$
\text { simpul 18: } Y_{W}=1
$$

Masalah program linier di atas diselesaikan dengan menggunakan solver program linier pada Microsoft Excel 2010 ditampilkan pada Tabel 3. Dari tabel tersebut diperoleh jalur kritis:

Mulai $\rightarrow A \rightarrow B \rightarrow C \rightarrow D \rightarrow E \rightarrow G \rightarrow H \rightarrow I \rightarrow K \rightarrow L \rightarrow Q \rightarrow R \rightarrow S \rightarrow$ $U \rightarrow W \rightarrow$ Selesai,

dengan durasi penyelesaian proyek pada kondisi normal (tanpa penundaan) adalah selama 77 minggu.

Untuk mempercepat penyelesaian proyek pembangunan apartemen sampai pada waktu yang diinginkan, perusahaan konstruksi Reliable Co dapat melakukan crashing pada setiap kegiatan, yang tentu saja memerlukan biaya tambahan (atau disebut biaya crash). Pada Tabel 4 (kolom 3 dan 5) diberikan data waktu dan biaya crash yang dirancang oleh perusahaan Reliable Co di setiap kegiatan proyek.

Untuk menentukan kegiatan mana saja yang akan di-crash dan seberapa besar waktu reduksinya, maka dicari terlebih dahulu waktu reduksi maksimum, dan tambahan biaya dengan adanya crash per minggu ( diistilahkan dengan "biaya crash per minggu" ) untuk setiap kegiatan dengan menggunakan rumus:

$$
\begin{gathered}
\text { waktu reduksi maksimum }=\text { waktu normal }- \text { waktu crash }, \\
\text { biaya crash per minggu }=\frac{\text { biaya crash }- \text { biaya normal }}{\text { waktu reduksi maksimum }} .
\end{gathered}
$$

Pada Tabel 4 kolom 6 dan 7 ditampilkan hasil perhitungan waktu reduksi maksimum dan biaya crash per minggu untuk setiap kegiatan. 
Tabel 4. Data Time-Cost Trade-Off dari Proyek Konstruksi Reliable Co

\begin{tabular}{|c|c|c|c|c|c|c|}
\hline Kegiatan & $\begin{array}{c}\text { Waktu } \\
\text { Normal }\end{array}$ & $\begin{array}{c}\text { Waktu } \\
\text { Crash }\end{array}$ & $\begin{array}{c}\text { Biaya } \\
\text { Normal }\end{array}$ & $\begin{array}{c}\text { Biaya } \\
\text { Crash }\end{array}$ & $\begin{array}{c}\text { Waktu Reduksi } \\
\text { Maksimum }\end{array}$ & $\begin{array}{c}\text { Biaya Crash } \\
\text { Per minggu }\end{array}$ \\
\hline$A$ & 2 minggu & 1 minggu & $\$ 20,000$ & $\$ 30,000$ & 1 minggu & $\$ 10,000$ \\
$B$ & 3 minggu & 1 minggu & $\$ 60,000$ & $\$ 100,000$ & 2 minggu & $\$ 2,000$ \\
$C$ & 2 minggu & 1 minggu & $\$ 30,000$ & $\$ 40,000$ & 1 minggu & $\$ 10,000$ \\
$D$ & 2 minggu & 1 minggu & $\$ 20,000$ & $\$ 30,000$ & 1 minggu & $\$ 10,000$ \\
$E$ & 4 minggu & 2 minggu & $\$ 100,000$ & $\$ 150,000$ & 2 minggu & $\$ 25,000$ \\
$F$ & 3 minggu & 2 minggu & $\$ 150,000$ & $\$ 180,000$ & 1 minggu & $\$ 30,000$ \\
$G$ & 2 minggu & 1 minggu & $\$ 200,000$ & $\$ 300,000$ & 1 minggu & $\$ 100,000$ \\
$H$ & 10 minggu & 7 minggu & $\$ 500,000$ & $\$ 620,000$ & 3 minggu & $\$ 40,000$ \\
$I$ & 15 minggu & 10 minggu & $\$ 650,000$ & $\$ 850,000$ & 5 minggu & $\$ 40,000$ \\
$J$ & 7 minggu & 5 minggu & $\$ 250,000$ & $\$ 300,000$ & 2 minggu & $\$ 25,000$ \\
$K$ & 2 minggu & 1 minggu & $\$ 20,000$ & $\$ 25,000$ & 1 minggu & $\$ 5,000$ \\
$L$ & 9 minggu & 6 minggu & $\$ 300,000$ & $\$ 420,000$ & 3 minggu & $\$ 40,000$ \\
$M$ & 2 minggu & 1 minggu & $\$ 20,000$ & $\$ 25,000$ & 1 minggu & $\$ 5,000$ \\
$N$ & 3 minggu & 2 minggu & $\$ 30,000$ & $\$ 40,000$ & 1 minggu & $\$ 10,000$ \\
$O$ & 6 minggu & 4 minggu & $\$ 120,000$ & $\$ 150,000$ & 2 minggu & $\$ 15,000$ \\
$P$ & 7 minggu & 4 minggu & $\$ 450,000$ & $\$ 570,000$ & 3 minggu & $\$ 40,000$ \\
$Q$ & 4 minggu & 2 minggu & $\$ 350,000$ & $\$ 500,000$ & 2 minggu & $\$ 75,000$ \\
$R$ & 6 minggu & 3 minggu & $\$ 550,000$ & $\$ 760,000$ & 3 minggu & $\$ 70,000$ \\
$S$ & 7 minggu & 5 minggu & $\$ 450,000$ & $\$ 600,000$ & 2 minggu & $\$ 75,000$ \\
$T$ & 5 minggu & 3 minggu & $\$ 350,000$ & $\$ 450,000$ & 2 minggu & $\$ 50,000$ \\
$U$ & 5 minggu & 3 minggu & $\$ 250,000$ & $\$ 320,000$ & 2 minggu & $\$ 35,000$ \\
$V$ & 4 minggu & 2 minggu & $\$ 150,000$ & $\$ 220,000$ & 2 minggu & $\$ 35,000$ \\
$W$ & 4 minggu & 2 minggu & $\$ 100,000$ & $\$ 150,000$ & 2 minggu & $\$ 25,000$ \\
\hline
\end{tabular}

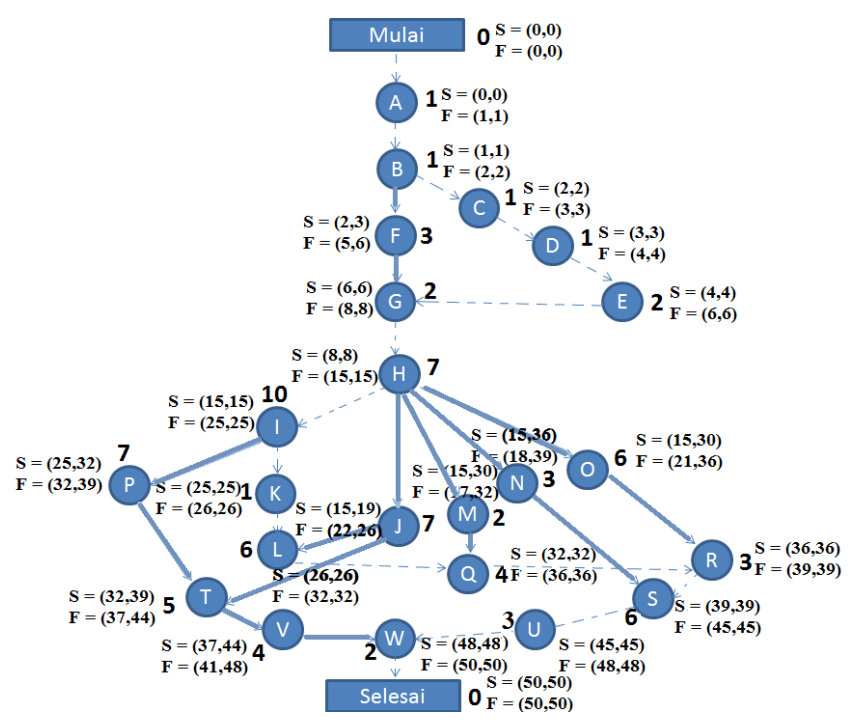

Gambar 4. Jaringan Proyek Konstruksi Reliable Co setelah dilakukan Crashing

Jadi, proyek konstruksi Reliable Co dengan melakukan crash dapat diselesaikan selama 50 minggu dengan total biaya adalah biaya normal $(\$ 5.120 .000)+$ biaya $\operatorname{crash}(\$ 970.000)=\$ 6.090 .000$. Diagram jaringan proyek konstruksi setelah di-crash ditunjukkan oleh Gambar 3.3.6, dimana panah dengan garis putus-putus menunjukkan jalur kritis pada jaringan proyek.

Penentuan kegiatan crashing pada jalur kritis suatu proyek dapat lebih mudah dilakukan dengan menggunakan program linier.

Variabel keputusan sebagai berikut:

$x_{j}=$ reduksi pada durasi kegiatan $j$ yang akan di-crash, untuk $j=A, B, \ldots, W$. $y_{\text {selesai }}=$ durasi proyek, yaitu waktu saat simpul "selesai" pada jaringan proyek 
170 Risna Julita dkk.

tercapai.

$y_{j}=$ waktu mulai kegiatan ke- $j$, untuk $j=B, C, \ldots, W$, jika diberikan nilai $x_{A}, x_{B}$, $\ldots, x_{W}$.

Waktu untuk memulai setiap kegiatan (termasuk "selesai") langsung berhubungan dengan waktu mulai dan durasi dari setiap kegiatan pendahulunya sebagaimana yang dirumuskan sebagai berikut:

Untuk setiap kegiatan $(B, C, \ldots, W$,"Selesai") dan setiap kegiatan pendahulunya, berlaku:

waktu mulai kegiatan $\geq$ (waktu mulai + durasi) dari kegiatan pendahulunya .

Dengan menggunakan waktu normal pada Tabel 4, durasi dari setiap kegiatan dirumuskan sebagai berikut:

Durasi dari kegiatan $j=$ waktu normal kegiatan $j-x_{j}$.

Dengan demikian, model program linier secara lengkap untuk masalah crashing proyek adalah sebagai berikut:

Fungsi Tujuan:

Min $Z=10000 x_{A}+20000 x_{B}+\ldots+25000 x_{W}$,

dengan kendala:

(1) Kendala reduksi maksimum:

Dengan menggunakan kolom ke-6 pada Tabel 4,

$x_{A} \leq 1, x_{B} \leq 2, \ldots, x_{W} \leq 2$.

(2) Kendala non-negatif:

$x_{A} \geq 0, x_{B} \geq 0, \ldots, x_{W} \geq 0$.

$y_{B} \geq 0, y_{C} \geq 0, \ldots, y_{W} \geq 0, y_{\text {Selesai }} \geq 0$.

(3) Kendala waktu mulai:

Terdapat dua tipe yaitu kendala dengan satu kegiatan pendahulu dan kendala dengan lebih dari satu kegiatan pendahulu.

Kendala dengan satu kegiatan pendahulu:

\begin{tabular}{lc}
\hline$y_{B} \geq y_{A}+2-x_{A}$ & $y_{K} \geq y_{I}+15-x_{I}$ \\
$y_{C} \geq y_{B}+3-x_{B}$ & $y_{M} \geq y_{H}+10-x_{H}$ \\
$y_{D} \geq y_{C}+2-x_{C}$ & $y_{N} \geq y_{H}+10-x_{H}$ \\
$y_{E} \geq y_{D}+2-x_{D}$ & $y_{O} \geq y_{H}+10-x_{H}$ \\
$y_{F} \geq y_{B}+3-x_{B}$ & $y_{P} \geq y_{I}+15-x_{I}$ \\
$y_{G} \geq y_{F}+3-x_{F}$ & $y_{U} \geq y_{S}+7-x_{S}$ \\
$y_{H} \geq y_{G}+2-x_{G}$ & $y_{V} \geq y_{T}+5-x_{t}$ \\
$y_{I} \geq y_{H}+10-x_{H}$ & $y_{\text {Selesai }} \geq y_{W}+4-x_{W}$. \\
$y_{J} \geq y_{H}+10-x_{H}$ & \\
Kendala dengan lebih dari satu kegiatan pendahulu: \\
\hline$y_{J} \geq y_{K}+2-x_{K}$ & $y_{S} \geq y_{N}+3-x_{N}$ \\
$y_{J} \geq y_{J}+7-x_{J}$ & $y_{S} \geq y_{R}+6-x_{R}$ \\
$y_{Q} \geq y_{M}+2-x_{M}$ & $y_{T} \geq y_{P}+7-x_{P}$ \\
$y_{Q} \geq y_{L}+9-x_{L}$ & $y_{T} \geq y_{J}+7-x_{J}$
\end{tabular}


Tabel 5. Hasil Perhitungan Solusi Optimal dari Proyek Konstruksi Reliable Co dengan Menggunakan Solver Program Linier pada Microsoft Excel 2010

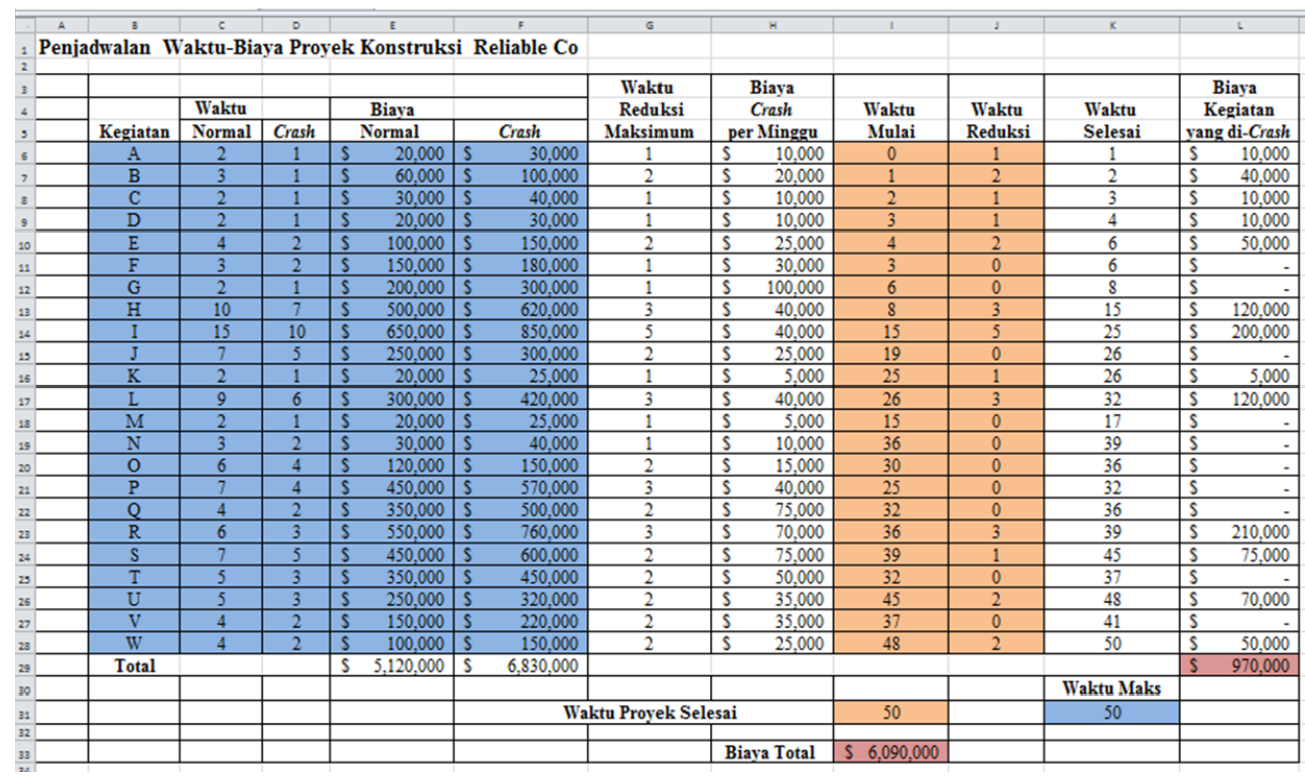

$$
\begin{array}{ll}
y_{R} \geq y_{O}+6-x_{O} & y_{W} \geq y_{U}+5-x_{U} \\
y_{R} \geq y_{Q}+4-x_{Q} & y_{W} \geq y_{V}+4-x_{V} .
\end{array}
$$

(4) Kendala durasi proyek:

$y_{\text {Selesai }} \geq 50$.

Penyelesaian model program linier pada formulasi di atas dapat dicari dengan menggunakan solver program linier pada Microsoft Excel 2010 (dalam hal ini digunakan metode simpleks) diberikan pada Tabel 3.3.8, dimana solusi optimalnya ditunjukkan pada kolom ke- $J$, yaitu:

$x_{A}=1, x_{B}=2, x_{C}=1, x_{D}=1, x_{E}=2, x_{H}=3, x_{I}=5, x_{L}=3, x_{R}=3, x_{S}=1$, $x_{U}=2, x_{W}=2$.

Dari solusi tersebut diperoleh bahwa biaya total adalah biaya normal + biaya crash $=\$ 5,120,000+\$ 970,000=\$ 6,090,000$. Biaya total tersebut masih lebih kecil sebesar $\$ 410,000$ dari harga tender yang diberikan, yaitu $\$ 6,500,000$. Karena perusahaan dapat menyelesaikan proyek lebih cepat, yaitu selama 50 minggu, maka sesuai dengan kontrak, perusahaan mendapatkan bonus sebesar $\$ 990,000$.

Jadi total keuntungan yang diperoleh oleh perusahaan adalah sebesar $\$ 410,000$ $+\$ 990,000=\$ 1,400,000$. Keuntungan yang diperoleh dengan melakukan crashing ini lebih besar $\$ 20,000$ jika dibandingkan dengan keuntungan yang diperoleh pada kondisi normal (yaitu sebesar $\$ 1,380,000$ ). Dengan demikian pengerjaan proyek dengan melakukan crashing lebih baik dari pada kondisi normal, karena perusahaan memperoleh keuntungan yang lebih tinggi lagi. 


\section{Kesimpulan}

Pada paper ini, penulis membahas tentang metode jalur kritis dan pendekatan program linier dalam menyelesaikan masalah manajemen suatu proyek dengan kasus proyek yang ada pada referensi [5]. Metode jalur kritis dan pendekatan program linier ini memberikan hasil yang sama untuk jalur kritis pada kondisi normal (tidak ada penundaan pada setiap kegiatan proyek) dan keputusan crashing.

Dari permasalahan yang dibahas dapat disimpulkan bahwa pengerjaan proyek dengan melakukan crashing lebih baik dari pada kondisi normal, karena dengan melakukan crashing perusahaan memperoleh keuntungan yang lebih besar.

\section{Ucapan Terima kasih}

Penulis mengucapkan terima kasih kepada Ibu Dr. Susila Bahri, Bapak Efendi, M. Si dan Bapak Bukti Ginting, M.Si yang telah memberikan masukan dan saran sehingga paper ini dapat diselesaikan dengan baik.

\section{Daftar Pustaka}

[1] Aminudin. 2005. Prinsip-prinsip Riset Operasi. Erlangga, Jakarta.

[2] J Arifudin, Riza. 2012. Optimasi Penjadwalan Proyek dengan Penyeimbangan Biaya Menggunakan Kombinasi CPM dan Algoritma Genetika. Jurnal Masyarakat Informatika.4.2:1 - 14 .

[3] Hillier, S. Frederick, Gerald J. Lieberman. 2015. Introduction to Operations Research. Tenth Edition. McGraw-Hill Education, New York.

[4] Khalaf, S. Wakas dan Leong Wah June. 2009. A Linear Programming Approach for the Project Controlling. Research Journal of Applied Sciences.4.5: 202 - 212.

[5] Moder, J. Joseph,et.al. 1983. Project Management with CPM, PERT and Precedence Diagramming. Third Edition. Van Nostrand Reinhold, New York. 